\title{
Some electrocardiographic values of Angora goats
}

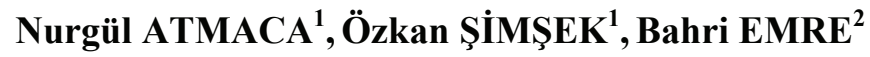 \\ ${ }^{1}$ Kırıkkale University, Faculty of Veterinary Medicine, Department of Physiology, Kırıkkale; ${ }^{2}$ Ankara University, Faculty of \\ Veterinary Medicine, Department of Physiology, Ankara, Turkey.
}

Summary: Electrocardiography is a noninvasive and easily applied technique used in the determination of cardiac hypertrophy and dilatation, the classification of cardiac arrhythmias, and the diagnosis of conduction abnormalities. The aim of this study was to determine the normal electrocardiographic (ECG) values in Angora goats. A total of 30 healthy Angora goats of both sexes, ranging in age from 1 to 2 years, were used in the study. The 3 standard bipolar limb leads (I, II, III) and unipolar augmented limb leads (aVR, aVL, aVF) were recorded with the goats standing. The morphology and amplitude of P waves, QRS complexes, and $\mathrm{T}$ waves were analyzed in all leads. Cardiac rhythm, heart rate, and the durations of $\mathrm{P}, \mathrm{QRS}$ and $\mathrm{T}$ waves, as well as the PR interval and QT interval, were calculated in the limb leads. The mean electrical axis for each individual was determined from the net amplitude of the QRS complex in leads I and III. Most of the animals had sinus rhythm. The mean heart rate was $108.71 \pm 3.289$ per minute and ranged from 75 to 143 . The mean electrical axis was between $-178^{\circ}$ and $+170^{\circ}$. In conclusion, the findings presented here may be useful to clinicians and researchers as reference values for the normal ECG of Angora goats.

Keywords: Angora goat, configuration, electrocardiogram, wave.

\section{Ankara keçilerinde bazı elektrokardiyografik değerler}

Özet: Non-invaziv ve kolayca uygulanan elektrokardiyografi; kalpteki dilatasyon ve hipertrofilerin belirlenmesinde, kardiyak aritmilerin sınıflandırılmasında ve iletim bozukluklarının teşhisinde kullanılan bir tekniktir. Bu çalışmada Ankara keçilerine ait bazı elektrokardiyografik değerlerin ortaya konulması amaçlandı. Çalışmada her iki cinsiyetten, 1-2 yaş arası, toplam 30 tane sağlıklı Ankara keçisi kullanıldı. Hayvanlardan ayakta bipolar ekstremite derivasyonları (I, II, III) ve artırılmış unipolar ekstremite derivasyonlarının (aVR, aVL, aVF) kayıtları alındı. Tüm derivasyonlarda P dalgası, QRS kompleksi ve T dalgalarının morfolojileri ve amplitüdleri belirlendi. Ayrıca kalp ritmi ve dakika kalp atım sayısının yanısıra ekstremite derivasyonlarının tümünde $\mathrm{P}$, QRS ve T dalgaları, PR aralığı ve QT aralığı süreleri hesaplandı. Her bir hayvan için I ve III. derivasyonlardaki net QRS kompleksi amplitüdünden ortalama elektriksel eksen belirlendi. Hayvanların çoğunda sinus ritmi bulundu. Dakika kalp atım sayısı ortalama 108,71 $\pm 3,289$, değişim aralığı ise 75-143 adet/dk olarak belirlendi. Ortalama elektriksel eksen $-178^{\circ}$ ile $+170^{\circ}$ arasında hesapland1. Sonuç olarak, bu araştırmadan elde edilen bulguların Ankara keçilerine ait normal EKG değerleri ile ilgili bir referans olarak klinisyen ve araştırmacılara faydalı olacağı düşünülmektedir.

Anahtar kelimeler: Ankara keçisi, dalga, elektrokardiyogram, konfigürasyon.

\section{Introduction}

Electrocardiography in clinical practice is the recording at the body surface of electrical fields generated by the heart (23). The electrocardiogram is the initial test of choice to evaluate cardiac problems associated with the initiation and conduction of waves of depolarization (21). Most of the literature on electrocardiography in domestic animals, a method commonly used in the diagnosis of cardiac arrhythmias, is focused on dogs and horses, as reported by Mohan et al (13).

Studies showed that breed and age in dogs $(4,8,14$, $15,20)$ and age in horses $(3,11)$ were factors that play an important role in affecting electrocardiographic (ECG) parameters. In the meantime use of goats for biomedical research has demonstrated that they offer potential advantages. For instance the goat has a small body size, reproduces easily, and costs little in monetary terms, which makes it preferable to other ruminants for biological research (23). Recently studies have been performed to investigate the normal ECG values in different goat breeds $(1,13,16,17)$ and the effect of various chemicals on the goat heart $(9,10,12,19)$.

The present study was undertaken to establish the ECG patterns in Angora goats, and to provide information on the heart rate and rhythm, the duration and amplitude of ECG deflections, and the mean electrical axis in this breed. 


\section{Materials and methods}

This study was performed at Lalahan Livestock Central Research Institute with the permission of the Directorate. A total of 30 healthy Angora goats of both sexes, aged 1 to 2 years, were used in the study.

The 3 standard bipolar limb leads (I, II, III) and the augmented unipolar limb leads (aVR, aVL, aVF) were recorded with the goats in a standing position, without sedation and under minimal restraint, using alligator clip electrodes with a little cardiac gel applied just below the elbow and stifle joints of the forelimb and hind limb, respectively, according to the Upadhyay method (25). All the ECG recordings were made during the morning hours, using a 3-channel electrocardiograph (Edan Instruments, Inc, VE-300, China). All recordings were standardized at $1 \mathrm{mV}=10 \mathrm{~mm}$, with a chart speed of 50 $\mathrm{mm} / \mathrm{s}$. The morphology and amplitude of P waves, QRS complexes, and $\mathrm{T}$ waves were analyzed in all 6 leads. Cardiac rhythm, heart rate, and durations of P, QRS and $\mathrm{T}$ waves, as well as the PR interval and QT interval, were calculated in the limb leads. The mean electrical axis for each individual was determined from the net amplitude of the QRS complex in leads I and III.
Typical descriptive statistical methods were used to calculate the mean, standard error, minimum and maximum values. Statistical analysis was performed using SPSS 10.0 for Windows (SPSS, Inc, USA). Descriptive statistic results were presented as mean \pm standard error (SE), minimum and maximum of values for each parameter.

\section{Results}

The ECG amplitude and duration parameters derived from the recorded leads are shown in Table 1. Most of the animals had sinus rhythm. The mean heart rate was $108.71 \pm 3.289$ per minute and ranged from 75 to 143 . The mean electrical axis was between $-178^{\circ}$ and $+170^{\circ}$.

An analysis of the morphology of the $\mathrm{P}$ wave, the $\mathrm{T}$ wave is presented in Tables 2 and the QRS complex, in Tables 3. Electrocardiograms of Angora goats revealed generally positive $\mathrm{P}$ waves in all leads, except for aVR and aVL. It was determined that the QRS complex in the ECG traces of Angora goats has a predominant configuration QS in I and aVL leads and qr in II, III and aVF leads and $r$ in aVR lead. The QRS complex was

Table 1. Amplitude and duration of the various electrocardiographic waves in standard bipolar limb leads (I, II, III) and unipolar augmented limb leads (aVR, aVL, aVF) in Angora goats (mean \pm SE, $n=30$ ).

Tablo 1. Ankara keçilerinde standart bipolar ekstremite derivasyonları (I, II, III) ve artırılmış unipolar ekstremite derivasyonlarında (aVR, aVL, aVF) çeşitli elektrokardiyografik dalgaların süre ve amplitüdleri (ortalama $\pm \mathrm{SH}, \mathrm{n}=30$ ).

\begin{tabular}{lcccccc}
\hline Parameter & I & II & III & aVR & aVL & aVF \\
\hline P-wave duration (s) & $0.02 \pm 0.001$ & $0.02 \pm 0.001$ & $0.02 \pm 0.001$ & $0.02 \pm 0.001$ & $0.02 \pm 0.001$ & $0.02 \pm 0.001$ \\
& $(0.02-0.04)$ & $(0.01-0.03)$ & $(0.01-0.04)$ & $(0.01-0.04)$ & $(0.01-0.03)$ & $(0.01-0.04)$ \\
P-wave amplitude (mV) & $0.06 \pm 0.005$ & $0.06 \pm 0.004$ & $0.05 \pm 0.003$ & $0.06 \pm 0.004$ & $0.05 \pm 0.002$ & $0.05 \pm 0.001$ \\
& $(0.05-0.10)$ & $(0.05-0.10)$ & $(0.03-0.10)$ & $(0.05-0.10)$ & $(0.05-0.10)$ & $(0.05-0.05)$ \\
& $0.04 \pm 0.001$ & $0.03 \pm 0.002$ & $0.04 \pm 0.001$ & $0.03 \pm 0.001$ & $0.04 \pm 0.001$ & $0.04 \pm 0.002$ \\
QRS-complex duration (s) & $(0.02-0.05)$ & $(0.02-0.05)$ & $(0.03-0.05)$ & $(0.02-0.04)$ & $(0.02-0.04)$ & $(0.03-0.06)$ \\
& $0.06 \pm 0.002$ & $0.05 \pm 0.002$ & $0.05 \pm 0.002$ & $0.05 \pm 0.002$ & $0.05 \pm 0.002$ & $0.035 \pm 0.001$ \\
T-wave duration (s) & $(0.03-0.06)$ & $(0.03-0.06)$ & $(0.04-0.06)$ & $(0.03-0.08)$ & $(0.02-0.06)$ & $(0.02-0.05)$ \\
& $0.27 \pm 0.022$ & $0.20 \pm 0.018$ & $0.14 \pm 0.010$ & $0.24 \pm 0.018$ & $0.22 \pm 0.017$ & $0.11 \pm 0.008$ \\
T-wave amplitude (mV) & $(0.10-0.60)$ & $(0.10-0.50)$ & $(0.05-0.30)$ & $(0.10-0.50)$ & $(0.05-0.40)$ & $(0.05-0.20)$ \\
& $0.09 \pm 0.003$ & $0.09 \pm 0.003$ & $0.08 \pm 0.003$ & $0.09 \pm 0.003$ & $0.08 \pm 0.002$ & $0.09 \pm 0.003$ \\
PR interval (s) & $(0.06-0.12)$ & $(0.05-0.12)$ & $(0.06-0.11)$ & $(0.06-0.10)$ & $(0.06-0.12)$ & $(0.06-0.10)$ \\
& $0.25 \pm 0.005$ & $0.24 \pm 0.004$ & $0.24 \pm 0.005$ & $0.25 \pm 0.005$ & $0.24 \pm 0.006$ & $0.23 \pm 0.005$ \\
QT interval (s) & $(0.22-0.32)$ & $(0.18-0.28)$ & $(0.16-0.28)$ & $(0.18-0.30)$ & $(0.16-0.28)$ & $(0.18-0.30)$ \\
& &
\end{tabular}

The values in the parenthesis indicates range. (Parantez içindeki değerler değişim aralığını göstermektedir.)

Table 2. Configurations of $\mathrm{P}$ and $\mathrm{T}$ waves $(\%)$ in Angora goats $(\mathrm{n}=30)$.

Tablo2. Ankara keçilerinde ( $\mathrm{n}=30) \mathrm{P}$ ve T dalgası konfigürasyonları (\%).

\begin{tabular}{|c|c|c|c|c|c|c|}
\hline \multirow[b]{2}{*}{ Leads } & \multicolumn{3}{|c|}{$\mathrm{P}$ wave } & \multicolumn{3}{|c|}{$\mathrm{T}$ wave } \\
\hline & Positive & Negative & Isoelectric & Positive & Negative & Isoelectric \\
\hline I & 100 & & & 100 & & \\
\hline II & 100 & & & 100 & & \\
\hline III & 100 & & & 65 & 35 & \\
\hline $\mathrm{aVR}$ & & 100 & & & 100 & \\
\hline $\mathrm{aVL}$ & 22 & 78 & & 100 & & \\
\hline $\mathrm{aVF}$ & 62 & & 38 & 100 & & \\
\hline
\end{tabular}


Table 3. Configurations (\%) and amplitude (mV) of the QRS complex in Angora goats (mean \pm SE, $n=30$ ).

Tablo 3. Ankara keçilerinde ( $\mathrm{n}=30$ ) QRS kompleksinin konfigürasyonu (\%) ve amplitudü (ortalama $\pm \mathrm{SH}, \mathrm{mV}$ ).

\begin{tabular}{|c|c|c|c|c|c|c|}
\hline Configuration & I & II & III & aVR & $\mathrm{aVL}$ & $\mathrm{aVF}$ \\
\hline $\mathrm{r} \Lambda$ & & $\begin{array}{c}4 \\
(0.25 \pm 0.15)\end{array}$ & $\begin{array}{c}32 \\
(0.38 \pm 0.03)\end{array}$ & $\begin{array}{c}68 \\
(0.36 \pm 0.03)\end{array}$ & & $\begin{array}{c}24 \\
(0.34 \pm 0.02)\end{array}$ \\
\hline & & & $\begin{array}{c}23 \\
(0.72 \pm 0.04)\end{array}$ & $\begin{array}{c}20 \\
(0.68 \pm 0.04)\end{array}$ & & $\begin{array}{c}3 \\
0.06 \pm 0.01\end{array}$ \\
\hline $\mathrm{qr}-\sqrt{ }$ & & $\begin{array}{c}80 \\
(0.11 \pm 0.03)\end{array}$ & $\begin{array}{c}36 \\
(0.23 \pm 0.09)\end{array}$ & & & $\begin{array}{c}70 \\
(0.16 \pm 0.02)\end{array}$ \\
\hline$\sqrt{L R}$ & & & $\begin{array}{c}9 \\
(0.75 \pm 0.10)\end{array}$ & & & $\begin{array}{c}3 \\
(0.60 \pm 0.15)\end{array}$ \\
\hline$r s$ & $\begin{array}{c}7 \\
(0.25 \pm 0.15)\end{array}$ & & & $\begin{array}{c}12 \\
(0.17 \pm 0.07)\end{array}$ & $\begin{array}{c}7 \\
(0.15 \pm 0.05)\end{array}$ & \\
\hline QS & $\begin{array}{c}93 \\
(0.64 \pm 0.06)\end{array}$ & $\begin{array}{c}16 \\
(0.42 \pm 0.03)\end{array}$ & & & $\begin{array}{c}93 \\
(0.53 \pm 0.0 .05)\end{array}$ & \\
\hline
\end{tabular}
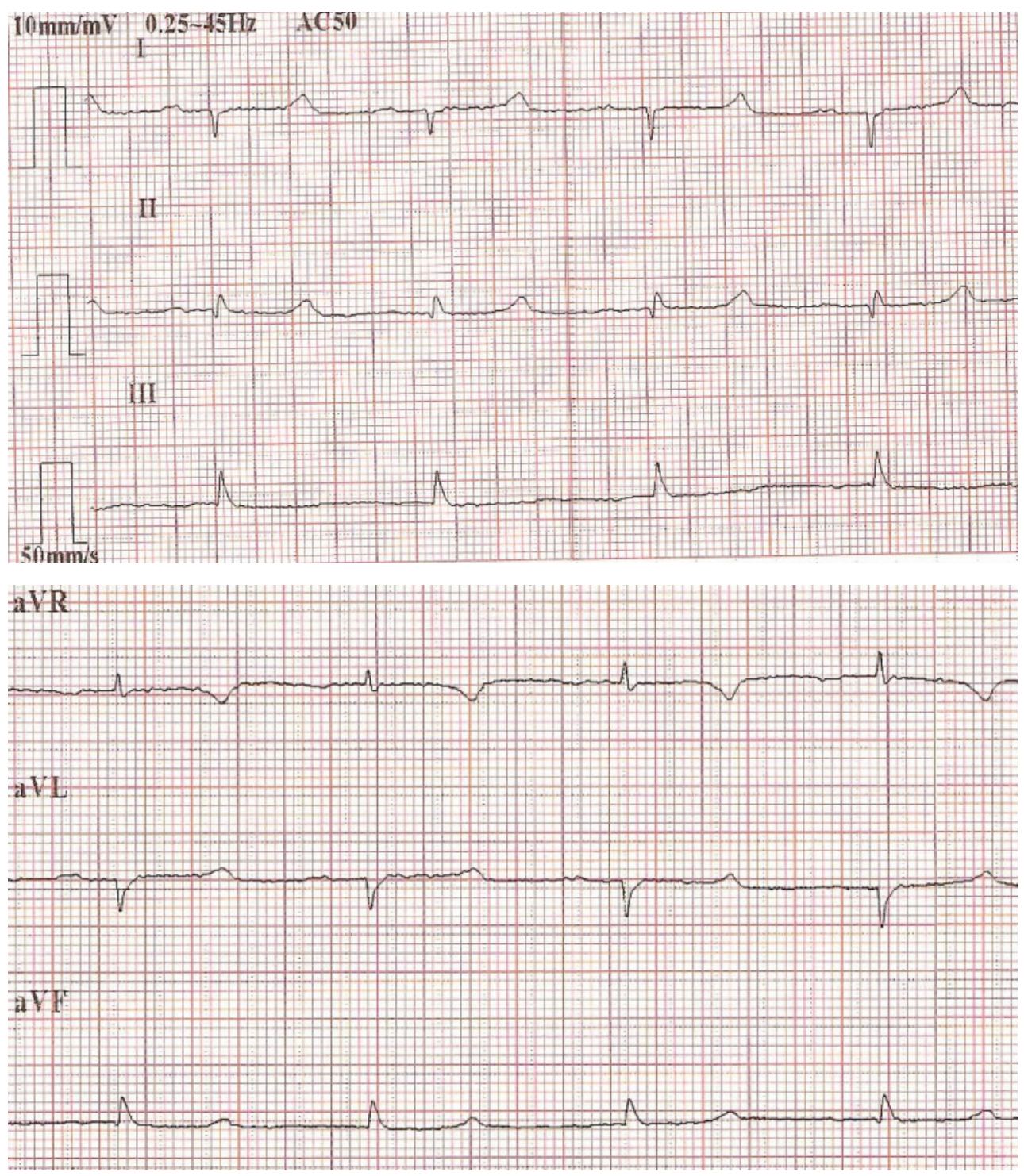

Figure 1. Example of Angora goat ECG $(50 \mathrm{~mm} / \mathrm{s} ; 10 \mathrm{~mm}=1 \mathrm{mV})$.

Şekil 1. Ankara keçisine ait elektrokardiyogram örneği $(50 \mathrm{~mm} / \mathrm{s} ; 10 \mathrm{~mm}=1 \mathrm{mV})$. 
observed to have monophasic and biphasic QRS configurations in all goats. $\mathrm{T}$ waves were observed positive direction in all leads, except for aVR lead. An example of a normal electrocardiogram of an Angora goat is shown in Figure 1.

\section{Discussion and Conclusion}

Electrocardiographic examination is one of the methods most commonly used for detecting cardiac arrhythmias in sheep and goats (5); however, it has been reported that ECG parameters can vary among different breeds of goat $(1,13,16,17)$. ECG studies in sheep and dogs have shown age-related variations $(2,24)$. But there were no major differences between sexes for ECG parameters of the dogs have been reported (8). In light of this information, the present study included animals of similar age group (between 1 to 2 years) and both sex in order to evaluate species-related differences.

In this study, wave amplitude and range values obtained from Angora goats were similar to those reported by previous studies in goats $(13,22)$. In addition, the mean values of ventricular depolarization, represented by the QRS complex amplitude, were lower than the values reported for dogs $(2,26)$. The Purkinje system in ruminants is deeply penetrating, and depolarization spreads explosively in many directions at once from ventricular endocardium to epicardium. Activation of the free wall spreads even more rapidly than in carnivores and primates, whose Purkinje fibers penetrate only a quarter of the endocardial-to-epicardial distance along the free walls (7). In the present study, the low-amplitude $\mathrm{R}$ waves observed were probably due to well synchronized ventricular depolarization.

The values we obtained for the PR interval, which represents the time interval between atrial and ventricular depolarization, and the QT interval, which begins with the onset of ventricular depolarization and ends with the completion of ventricular repolarization, were in line with earlier studies $(13,22)$.

As regards the P-wave morphology, our findings were similar to those of previous studies in goats (22). $\mathrm{P}$ waves were usually observed to have a positive orientation in all leads except aVR and aVL. In certain leads, the $\mathrm{P}$ waves could not be measured. This may have been due to a lack of coordinated atrial activity, so that $\mathrm{P}$ waves were not being formed, or it could be that $\mathrm{P}$ waves were present but were just not clear. The QRS complex was both monophasic and diphasic in different limb leads of Angora goats, as has been reported for other goat breeds $(1,16,22)$. Smith and Sherman (22) reported that the $\mathrm{T}$ wave in goats was generally sharp and positive, especially in lead III; the exception was lead aVL, which showed a negative $\mathrm{T}$ wave. In addition, Ahmed and Sanyal (1) determined that the $\mathrm{T}$ wave of goats was positive in leads I and II as is characteristic for goats. In this study, the $\mathrm{T}$ wave was sharp and orientated in a positive direction in lead I and II, which results were similar to those reported by Smith and Sherman (22).

A total of $84 \%$ animals had a sinus rhythm. Sinus arrhythmia was present in $16 \%$ animals. Previous studies have reported an incidence of respiratory sinus arrhythmia in goats of $10 \%$ to $20 \%(16,17)$, which is consistent with our findings. Assessment of the ECG recordings suggested that the sinus arrhythmia was related with respiration. It is commonly correlated with respiration in order that the discharge rate and heart rate increase during inspiration and decrease during expiration (18).

The heart of the goat is reported to vary in size and form according to the breed (6) and variations according to the breed were reflected in the ECG $(1,13)$. The mean heart rate was $108.71 \pm 3.289$ per minute and ranged from 75 to 143 . However, in this study, the heart rate of Angora goats was determined to be lower than that of Jamunapari goats (13) or Saanen goats (16), but similar to that of black Bengal goats (1). This variation in the frequency of heart rate among the breeds might be due to differences in the shape and size of the heart.

The mean electrical axis determines the site, size, and direction of the conduction system of the heart, which is characteristic of an individual or a breed (22). In the present study, the mean electrical axis ranged between $-178^{\circ}$ and $+170^{\circ}$, similar to that of black Bengal goats $\left(-187^{\circ}\right.$ to $\left.+158^{\circ}\right)$ (1). It was reported in previous studies that the value of the mean electrical axis was $37.34^{\circ}$ for Jamunapari goats (13) and $56.74^{\circ}$ for Kagani goats (19). This difference in the mean electrical axis values can be explained by breed diversity.

In conclusion, this study provides baseline information regarding ECG parameters in Angora goats. It contributes to the literature showing the effect of breed on ECG parameters and provides reference values of Angora goats for clinicians.

\section{References}

1. Ahmed JA, Sanyal S (2008): Electrocardiographic studies in Garol Sheep and Black Bengal Goats. Res J Cardiol, 1, 1-8.

2. Atmaca N, Emre B (2010): Some Electrocardiographic Parameters of the Kangal Dogs. J Anim Vet Adv, 9, 949953.

3. Ayala I, Montes A, Benedito JL, Castillo C, Hernandez J, Gutierrez C, Garcia-Partida P (1998): Modifications of the form and amplitude of the electrocardiographic $Q R S$ complex during growth in the Spanish-bred horse. J Vet Med A, 45, 309-317.

4. Bernal LJ, Montes AM, Fdez Palacio MJ, Gutierrez $\mathbf{P}$ (1995): Electrocardiographic changes in the growing Mastin Espanol. J Small Anim Pract 36, 221-228. 
5. Cebra C, Cebra M (2002): Diseases of the Cardiovascular System. 393-396. In: DG Pugh, editor. Sheep and Goat Medicine. 1st ed. WB Saunders, Philadelphia, USA.

6. Dyce KM, Sack WO, Wensing CJG (1987): Text Book of Veterinary Anatomy. Saunders, Philadelphia.

7. Hamlin RL, Glower DD, Pimmel RL (1984): Genesis of QRS in the ruminant: graphic simulation. Am J Vet Res, 45, 938-941.

8. Hanton G, Rabemampianina Y (2006): The electrocardiogram of the Beagle dog: reference values and effect of sex, genetic strain, body position and heart rate. Lab Anim, 40, 123-136.

9. Kant V, Srivastava AK, Verma PK, Raina R, Pankaj NK (2010): Alterations in electrocardiographic parameters after subacute exposure of flüoride and ameliorative action of aluminium sulphate in goats. Biol Trace Elem Res, 134, 188-194.

10. Kinjavdekar P, Amarpal GR, Pawde AM, Aithal HP (1999): Effects of subarachnoid xylazine and medetomidine on haemodynamics and ECG in goats. Zentralbl Veterinarmed A, 46, 271-275.

11. Lombard CW, Evans, M, Martin L (1984): Blood pressure, electrocardiogram and cardiogram measurements in the growing pony foal. Equine Vet J, 16, 342-347.

12. Madan AK, Korde JP, Das AK, Rastogi SK (2010): Propofol-induced electroencephalographic, electrocardiographic and spirometric changes in goats. Veterinarski Arhiv, 80, 27-39.

13. Mohan NH, Niyogi D, Singh HN (2005): Analysis of normal electrocardiograms of Jamunapari goats. $\mathrm{J}$ Vet Sci, 6, 295-298.

14. Oguchi Y, Hamlin RL (1993): Duration of QT interval in clinically normal dogs. Am J Vet Res, 54, 2145-2149.

15. Paslawska U (1998): The electrocardiographic curve of clinically healthy dogs of selected breeds. EJPAU, 1, 11-23.

16. Pogliani FC, Raimondo RFS, Monteiro BM, Filho JHHG (2010): The normal electrocardiogram in the clinically healthy Saanen goats. XXVI. Chile: World Buiatrics Congress.

17. Pourjafar M, BadIeI K, Chalmeh AA, Sanati AR, Shahbazi A, Badkobeh M, Bagheri MH (2012): Agerelated cardiac arrhythmias in clinically healthy Iranian Najdi goats. Bulg J Vet Med, 15, 37-43.
18. Radostits OM, Gay CC, Hinchcliff KW, Constable PD (2007): Diseases of the cardiovascular system. 399-438. In: OM Radostits, CC Gay, KW Hinchcliff. (Eds), Veterinary Medicine: A Text Book of the Diseases of Cattle, Horses, Sheep, Pigs and Goats, 10th ed., Elsevier, New York, USA.

19. Raina R, Verma PK, Pankaj NK, Prawez S, Srivastava AK (2008): Effects of tramadol on electrocardiogram, mean electrical axis and respiration in Kagani goats. Iran J Pharmacol Ther, 7, 157-160.

20. Rezakhani A, Atwell RB, Webster J (1990): Electrocardiographic values of German Shepherd dogs. Aust Vet J, 67, 307-309.

21. Santamarina GL, Espino L, Suarez LM (2001): Electrocardiographic parameters of free-ranging roe deer (Capreolus capreolus). J Zoo Wildlife Med, 32, 441-446.

22. Smith MC, Sherman DM (2009): Goat Medicine. 320322. In: MC Smith, DM Sherman (Eds), Cardiovascular System, 2nd ed., Wiley-Blackwell, Ames, Iowa.

23. Tilley LP, Smith FWK, Oyama MA, Sleeper MM (2008): Manual of Canine and Feline Cardiology. Elsevier Inc., Canada.

24. Tovar P, Santisteban R (1987): Effects of maturational changes upon the orientation of auricular activation vector in sheep. J Vet Med, 34, 18-24.

25. Upadhyay RC, Sud SC (1977): Electrocardiogram of the goat. Indian J Exp Biol, 15, 359-362.

26. Upeniece D (2004): Electrocardiophysiological parameters of the Cocker Spaniel Rottweiler and German Shepherd dogs. Summary of Doctoral Thesis, Latvia University of Agriculture Faculty of Veterinary Medicine Preclinical institute, Jelgava.

Geliş tarihi: 18.07.2013 / Kabul tarihi: 07.10.2013

Address for correspondence;

Assist. Prof. Dr. Nurgül Atmaca

Kırıkkale University,

Faculty of Veterinary Medicine,

Department of Physiology,

71451, Yahşihan-Kırıkkale.

e-mail:nurgulzengin@yahoo.com 